\title{
Microbial DNA extraction and analyses of soil iron-manganese nodules
}

\author{
Li-Mei Zhang ${ }^{\mathrm{a}}$, Fan Liu ${ }^{\mathrm{b}}$, Wen-Feng Tan ${ }^{\mathrm{b}}$, Xiong-Han Feng ${ }^{\mathrm{b}}$, \\ Yong-Guan $\mathrm{Zhu}^{\mathrm{a}}$, Jizheng $\mathrm{He}^{\mathrm{a}, *}$ \\ ${ }^{a}$ Research Center for Eco-Environmental Sciences, Chinese Academy of Sciences, Beijing 100085, China \\ ${ }^{\mathrm{b}}$ College of Resource and Environment, Huazhong Agricultural University, Wuhan 430070, China
}

Received 7 November 2006; received in revised form 18 December 2006; accepted 2 January 2007

Available online 8 February 2007

\begin{abstract}
Iron-manganese $(\mathrm{Fe}-\mathrm{Mn})$ nodules and concretions are soil new growth, reflecting soil environmental conditions during their formation. Bacteria play a dominant role in the oxidation of dissolved $\mathrm{Mn}$ (II) in aqueous systems and the formation of marine and freshwater Fe-Mn nodules. However, the role and significance of bacteria in soil Fe-Mn nodule formation have not been well recognized. In this paper, microbial DNA was directly extracted from two Fe-Mn nodule samples collected from Wuhan and Guiyang in central China. The extracted DNA was amplified by polymerase chain reaction (PCR) and cloned. The clones were then screened by amplified ribosomal DNA restriction analysis (ARDRA). Twenty patterns were obtained for Wuhan sample and Guiyang sample, respectively. DNA sequencing and phylogenetic analyses revealed that the bacterial compositions of the Fe-Mn nodules were mainly belonged to Firmicutes, $\beta$-proteobacteria, $\gamma$-proteobacteria branches of the domain bacteria. These divisions had close relativeness with $\mathrm{Mn}$ (II)-oxidizing bacteria identified from marine Fe-Mn nodules, implying the possible contributions of these bacteria to soil Fe-Mn nodule formation.
\end{abstract}

(C) 2007 Elsevier Ltd. All rights reserved.

Keywords: Soil Fe-Mn nodules; DNA extraction; 16S rDNA; ARDRA; Mn(II)-oxidizing bacteria

\section{Introduction}

Fe and Mn oxides (including hydroxides and oxyhydroxides), widespread in soils and sediments, play a critical role in the fate and transport of heavy metals and organic pollutants through sorptive, catalytic and oxidative processes. The formation of $\mathrm{Fe}-\mathrm{Mn}$ nodules and concretions in soil is regarded as the result of drying-wetting alternations of soil moisture and the corresponding oxidation and reduction cycles (Burns and Burns, 1975). $\mathrm{Fe}$ and $\mathrm{Mn}$ oxides release $\mathrm{Fe}(\mathrm{II})$ andMn (II) ions into the soil solution under the reducing conditions, and the Fe(II) and $\mathrm{Mn}(\mathrm{II})$ are oxidized into $\mathrm{Fe}(\mathrm{III})$ and $\mathrm{Mn}(\mathrm{III}, \mathrm{IV})$ and precipitated when the soil is dried out (McKenzie, 1989). Manganese is more mobile than $\mathrm{Fe}$ and requires a higher oxidation potential than $\mathrm{Fe}(\mathrm{II})$, resulting in the formation of alternate layers of Fe-rich and Mn-rich materials

\footnotetext{
${ }^{*}$ Corresponding author. Tel.: + 861062849788 ; fax: + 861062923563 .

E-mail address: jzhe@rcees.ac.cn (J. He).
}

observed in many nodules (White and Dixon, 1996). The elemental composition and distribution characteristics within the nodules may reflect their forming redox history of the pedoenvironment (McKenzie, 1989; Liu et al., 2002).

Microorganisms, especially bacteria, are known to catalyze the oxidation of $\mathrm{Mn}(\mathrm{II})$ and the formation of $\mathrm{Mn}(\mathrm{III}, \mathrm{IV})$ oxide minerals. Biological Mn(II) oxidation is generally much faster (by up to $10^{5}$ times) than abiotic $\mathrm{Mn}(\mathrm{II})$ oxidation processes, suggesting that biological $\mathrm{Mn}(\mathrm{II})$ oxidation dominates in the environment (Kim et al., 2003; Tebo et al., 2004). A number of investigations at specific field sites have shown that the biological processes are responsible for $\mathrm{Mn}$ (II) oxidation at those locations (e.g., Tebo and Emerson, 1985, 1986; Cowen et al., 1986, 1990; Tebo, 1991; Wehrli et al., 1995; Harvey and Fuller, 1998; van Cappellen et al., 1998; Fuller and Harvey, 2000; Kay et al., 2001). For these reasons, the majority of naturally occurring environmental Mn oxides are believed to be derived either directly from biogenic $\mathrm{Mn}(\mathrm{II})$ oxidation processes or from the subsequent 
alteration of the biogenic oxides (Tebo et al., 2004). Significant advances have been made in the last 10 years in the molecular biology of $\mathrm{Mn}(\mathrm{II})$ oxidation by three phylogenetically distinct bacteria representatives of different aqueous environmental settings: a marine Bacillus sp. strain SG-1; Leptothrix discophora strains SS-1 and SP-6, common in wetlands and in iron seeps and springs; and Pseudomonas putida strain MnB1, representative of freshwaters (Tebo et al., 1997). However, very little information is available about biological $\mathrm{Mn}$ oxidation in the soil environment. Douka (1977) isolated two Mn(II) oxidizing bacteria from manganese concretions of an alfisol soil of West Peloponnese in Greece. The bacteria were identified as Pseudomonas sp. nov. and Citrobacter freundii and their cell and the cell-free extracts could catalyze the formation of Mn precipitates. Sullivan and Koppi (1992) observed cell-like substances on the surface of manganese oxide coatings of a black earth (Typic Pellustert) in Australia using light microscopy and electron microscopy, suggesting microbial oxidation of $\mathrm{Mn}(\mathrm{II})$ contributed to the formation of the manganese oxide coatings in this soil.

In the present study, we improved soil DNA extraction methods and successfully extracted microbial DNA from soil $\mathrm{Fe}-\mathrm{Mn}$ nodules. The extracted DNA was polymerase chain reaction (PCR) amplified and cloned. The clones were then screened and sequenced. Phylogenetic analyses revealed that the bacterial compositions of the $\mathrm{Fe}-\mathrm{Mn}$ nodules were mostly belonged to Firmicutes, $\beta$-proteobacteria, $\gamma$-proteobacteria branches of the domain bacteria. Some of them had close relativeness with Mn(II)-oxidizing bacteria identified from the marine $\mathrm{Fe}-\mathrm{Mn}$ nodules, implying the possible contributions of these bacteria to the formation of soil $\mathrm{Fe}-\mathrm{Mn}$ nodules.

\section{Materials and methods}

\subsection{Sample collection}

$\mathrm{Fe}-\mathrm{Mn}$ nodules were collected from two different locations of Wuhan, Hubei Province and Guiyang, Hunan Province in central China. Wuhan sample (WH) was collected at a $40-\mathrm{cm}$ depth from the subsoil horizon of a subacid orthic agrudalf developed from Quaternary siliceous and alluvial sediments, and Guiyang sample (GY) was collected at $20-100 \mathrm{~cm}$ depth of an alt-udic ferrisol developed from rammell. Nodules were separated from the soil by wet sieving and stored at room temperature. The morphological properties, mineralogy, and chemical composition of the nodules have reported previously (Tan et al., 2000; Liu et al., 2002).

\subsection{DNA extraction from the $\mathrm{Fe}-\mathrm{Mn}$ nodules}

Before DNA extraction, $50 \mathrm{~g}$ of each sample was surface sterilized by rinsing in sterile distilled water for five times, immersing in $0.1 \% \mathrm{NaClO}$ for $1 \mathrm{~min}$, and then followed by five rinses in sterile distilled water. The nodules were ground to powder using a pestle and a mortar under asepsis condition. The control powder was autoclaved at $121^{\circ} \mathrm{C}$ for $30 \mathrm{~min}$ twice and dried at $100^{\circ} \mathrm{C}$ for $6 \mathrm{~h}$. DNA extraction was carried out with a combination of physical bead beating, chemical and biological lyses as described by Zhang et al. (2005) and $\mathrm{He}$ et al. (2005). Fe-Mn nodule powder was suspended in $143 \mathrm{ml}$ extraction buffer $(200 \mathrm{mM}$ $\mathrm{NaCl}, 200 \mathrm{mM}$ Tris, $2 \mathrm{mM}$ sodium citrate, $10 \mathrm{mM} \mathrm{CaCl}$, $50 \mathrm{mM}$ EDTA, adjusted to $\mathrm{pH} 8.0$ ), and then $1 \mathrm{ml}$ poly(A) $\left(10 \mathrm{mg} \mathrm{ml}^{-1}\right)$ and $4.5 \mathrm{ml} 10 \%$ pyrophosphate were added. The suspensions were treated with bead beater (Biospec Products, Bartlesville, OK) for $3 \mathrm{~min}$ in an ice bath after mixing with $40 \mathrm{~g}$ of 1 -mm-diameter silica beads and $5 \mathrm{~g}$ of $0.1-\mathrm{mm}$-diameter glass beads. They were incubated at $37^{\circ} \mathrm{C}$ for $2 \mathrm{~h}$ after $2 \mathrm{ml}$ lysozyme $\left(50 \mathrm{mg} \mathrm{ml}^{-1}\right)$ was added, and then $1 \mathrm{ml}$ protease $\mathrm{K}\left(20 \mathrm{mg} \mathrm{ml}^{-1}\right)$ and $10 \mathrm{ml} 20 \%$ SDS were added into. Subsequently, the suspensions were shaken at $250 \mathrm{rpm}$ for $1 \mathrm{~h}$ at $37^{\circ} \mathrm{C}$ and then incubated in a $65^{\circ} \mathrm{C}$ water bath for $1 \mathrm{~h}$ with end-over-end inversions every $10 \mathrm{~min}$ and centrifuged at $6000 \mathrm{~g}$ for $15 \mathrm{~min}$. The supernatants were extracted with an equal volume of phenol-chloroform-isoamyl alcohol (25:24:1, vol:vol:vol) and precipitated by adding 0.1 volume of $3 \mathrm{moll}^{-1}$ sodium acetate ( $\mathrm{pH} \mathrm{5.2)}$ and equal volume of cold isopropanol, washed with $75 \%$ ethanol, and resuspended in TE buffer (10 mM Tris-HCl, 1 mM EDTA, pH 8.0). The resuspended solution was re-extracted with phenol-chloroform-isoamyl alcohol (25:24:1) and precipitated with ethanol again (He et al., 2005). The control sample was subjected to the same DNA extraction procedures.

\subsection{PCR amplification, cloning, and amplified ribosomal $D N A$ restriction analysis ( $A R D R A$ )}

For amplification of $16 \mathrm{~S}$ rRNA gene of bacteria, the primers 27F (5'-AGA GTT TGA TCM TGG CTC AG) and 1492R (5'-TAC GGY TAC CTT GTT ACG ACT T) (Lane, 1991) were used in a standard 35-cycles PCR with an annealing temperature of $50^{\circ} \mathrm{C}$. The DNA extracts were 10 -fold diluted and used as a template. The $50-\mu 1$ reaction mixtures contained $1 \times$ PCR buffer, $400 \mathrm{nM}$ each primer, $2 \mathrm{mM} \mathrm{MgCl} 2,250 \mu \mathrm{M}$ each dNTP, $2.5 \mathrm{U}$ Taq DNA polymerase, $1 \mu \mathrm{l}$ of $20 \mathrm{mg} \mathrm{ml}^{-1}$ bovine serum albumin (BSA), and $2 \mu \mathrm{l}$ of DNA template. The amplified 16S rRNA gene fragments were ligated into the pGEM-T Easy Vector (Promega, Madison, WI), and the resulting ligation products were used for transformating into E. coli JM109 competent cells following the instructions of the manufacturer. 16S rRNA gene libraries were constructed and 40 randomly chosen colonies per sample were PCR reamplified using the primers of T7 and SP6. The amplicons were analyzed by restriction digestion with Hae III, Rsa I, and Hha I (New England Biolabs). The digested DNA fragments were run in $2 \%$ agarose gel electrophoresis. The ARDRA patterns were grouped by similarity and 1 or 2 representative clones from each group were sequenced. 


\subsection{Sequence analysis and GenBank accession numbers}

Double-stranded DNA sequencing was performed by Applied Biosystems 3730 automated sequencers with the primers T7 and SP6 to obtain nearly full-length (about $1500 \mathrm{bp}$ ) sequences of bacterial $16 \mathrm{~S}$ rRNA gene. The bidirectional gene sequences were compiled using DNAStar software 5.0 (DNAstar Inc., USA) and edited and aligned using Bio-Edit (Hall, 1999). Operational taxonomic units (OTUs) were defined as clones that shared $97 \%$ or greater sequence similarity. The sequences were then analyzed with the NCBI Blast program and RDP Chimera Check program. The most similar GenBank sequences to the clones were extracted from the GenBank for including in the phylogenetic tree construction. Phylogenetic analyzes were conducted using MEGA version 3.0 (Kumar et al., 2004) and a neighborjoining (NJ) tree was constructed using Kimura 2-parameter distance with 1000 replicates to produce Bootstrap values.

The sequences determined in this study were submitted to Genbank and assigned accession numbers from DQ351907 to DQ351929 and from DQ537525 to DQ537535.

\section{Results}

\subsection{DNA extraction and PCR amplification}

DNA extracts were run in $1 \%$ agarose gel electrophoresis but resulted in no detectable DNA band even if
$50 \mathrm{~g}$ samples were used, indicating very small amount of extractable DNA in the soil $\mathrm{Fe}-\mathrm{Mn}$ nodules. The 10-fold diluted DNA extracts were successfully amplified with the primers $27 \mathrm{~F}$ and $1492 \mathrm{R}$ and the products produced strong and sharp bands at about $1500 \mathrm{bp}$ on the subsequent agarose gel electrophoresis. No PCR product was detected from the diluted or undiluted control DNA template, and neither from undiluted DNA extracts.

\subsection{ARDRA of 16s $r D N A$ clones}

Each 40 clones randomly chosen from $\mathrm{WH}$ and $\mathrm{GY}$ clone libraries were re-amplified and digested with Hae III. The clones from WH and GY sample were grouped to 15 and 16 ARDRA patterns, respectively. Most of patterns contained 2-4 clones and partial patterns contained 1 or 6 clones. Fig. 1A shows the different restriction digestion patterns of WH clones with Hae III. Two or more clones that shared the same Hae III ARDRA pattern were digested further with $R s a$ I and $H h a$ I, and were regrouped to different ARDRA patterns (Fig. 1B). Similar banding patterns obtained after combination of the three independent digestions were grouped to finally obtain 20 groups for each sample. There were no significant differences in the ARDRA patterns between the WH and GY samples.
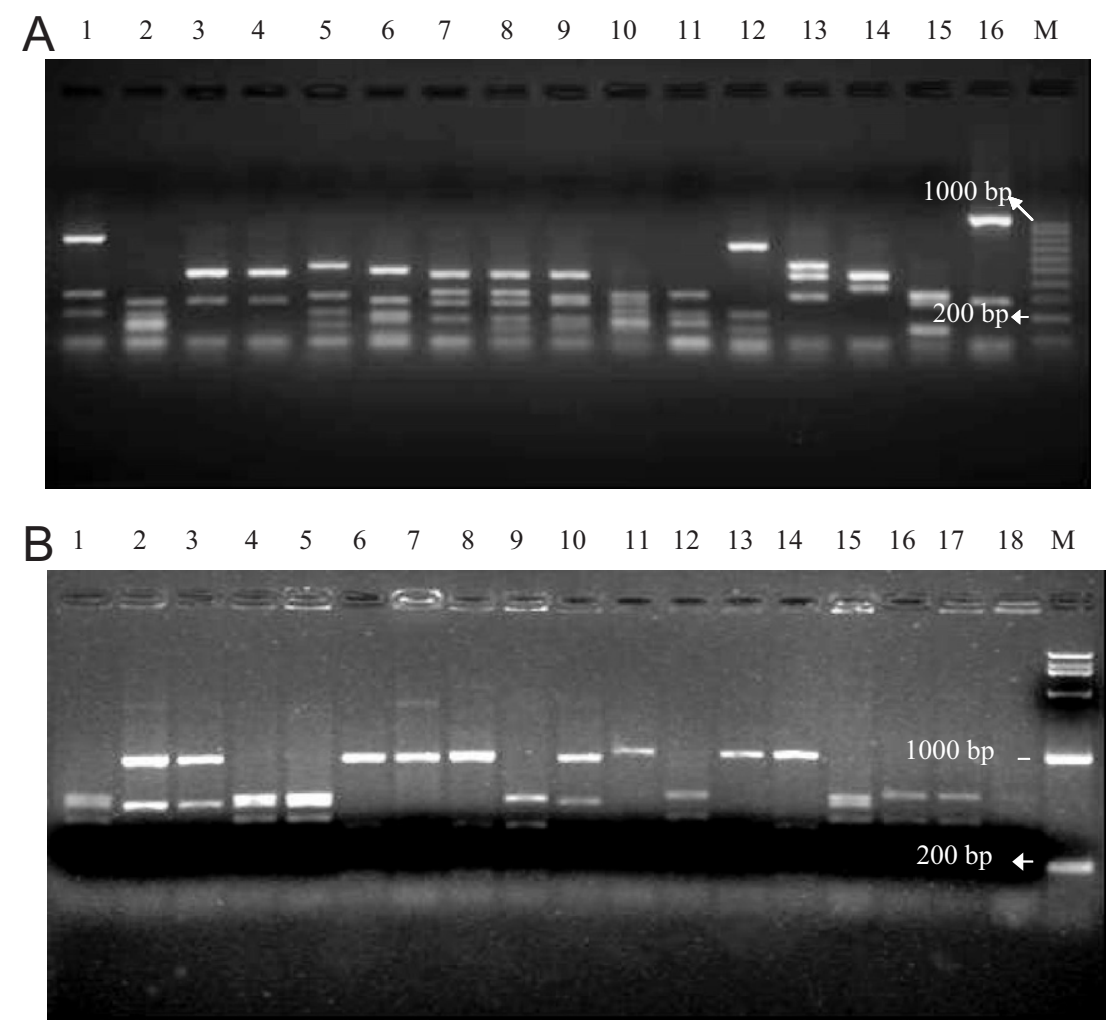

Fig. 1. Restriction patterns of 16S rDNA of clones digested with Hae III and Rsa I from the Wuhan Fe-Mn nodule sample. A 1-16: Different digestion patterns of WH clones with Hae III. B 1-19: Clones with the same Hae III ARDRA pattern were further digested to different patterns with Rsa I; 1-4, 5-6, 7-9, 10-11, 12-17 represented the same Hae III ARDRA pattern, respectively. M: DNA marker. 


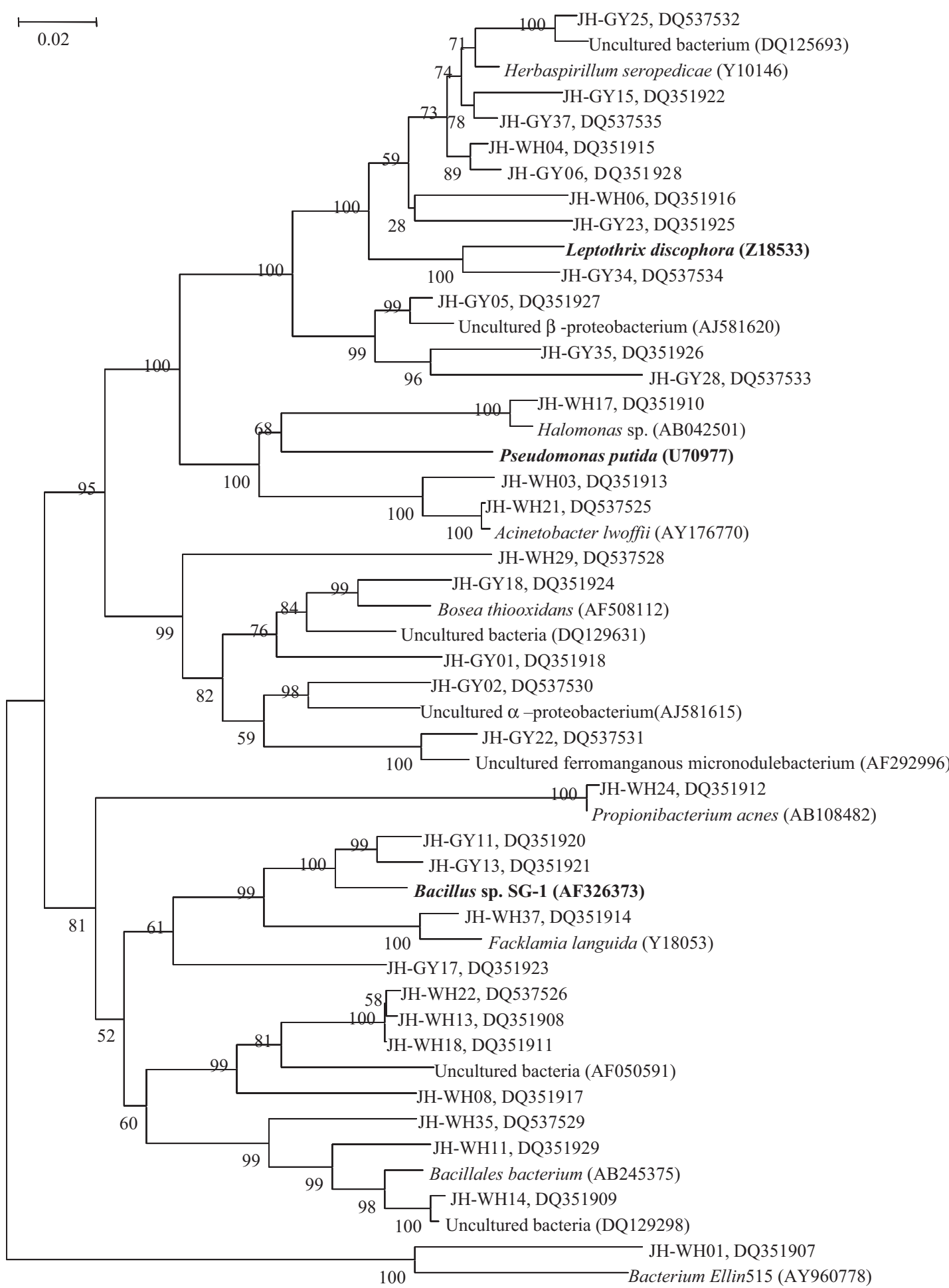

$\beta$-proteobacteria

$\gamma$-proteobacteria

$\alpha$-proteobacteria

Firmicutes

Actinobacteria

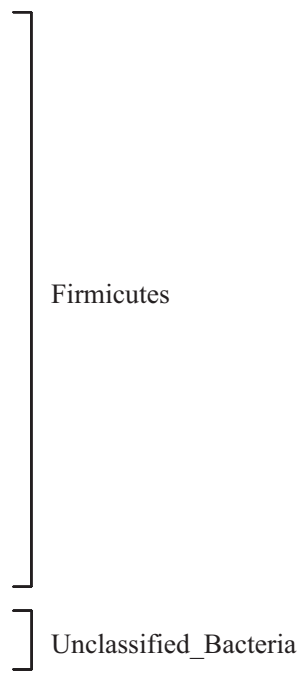

Fig. 2. Phylogenetic tree of $16 \mathrm{~S}$ rDNA clones from the Fe-Mn nodules and their most similar GenBank sequences. Numbers at branches are bootstrap values of 1000 replications. Phylum or class names of different groups of clones are assigned based on the relationships of the clones to the known GenBank species and the NCBI Bacterial Taxonomy classification. JH-WH denotes clones of the Wuhan sample and JH-GY of the Guiyang sample. The accession number is followed after each clone. Sequences in boldface are the model Mn-oxidizing bacteria from marine Fe-Mn nodules.

\subsection{Phylogeny of bacterial $16 \mathrm{~S} r \mathrm{DNA}$ clones in the $\mathrm{Fe}-\mathrm{Mn}$ nodules}

Each 20 clones representative of different restriction pattern from $\mathrm{WH}$ and GY sample were sequenced and assigned to 16 OTUs, respectively. A total of 32 unique OTUs were recovered from the 2 samples. The NJ tree of the clone sequences is shown in Fig. 2 and their taxonomic assignments are listed in Table 1. Among the 32 clones obtained in this study, each 11 clones were grouped into 
Table 1

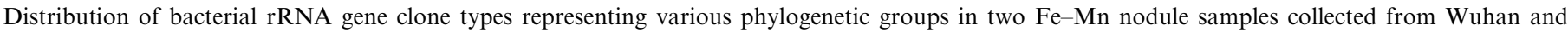
Guiyang of central China

\begin{tabular}{|c|c|c|c|c|c|c|}
\hline $\begin{array}{l}\text { Sample } \\
\text { Model bacteria }\end{array}$ & $\begin{array}{l}\text { Firmicutes } \\
\text { Bacillus sp. SG-1 }\end{array}$ & $\begin{array}{l}\beta \text {-Proteobacteria } \\
\text { Leptothrix discophora }\end{array}$ & $\begin{array}{l}\gamma \text {-Proteobacteria } \\
\text { Pseudomonas putida }\end{array}$ & $\alpha$-Proteobacteria & Actinobacteria & Unclassified_bacteria \\
\hline Wuhan & 8 & 2 & 3 & 1 & 1 & 1 \\
\hline Guiyang & 3 & 9 & 0 & 4 & 0 & 0 \\
\hline Total & 11 & 11 & 3 & 5 & 1 & 1 \\
\hline
\end{tabular}

Firmicutes and $\beta$-proteobacteria respectively, three clones into $\gamma$-proteobacteria and five clones into $\alpha$-proteobacteria, each one clones into Actinobacteria and unclassified bacterium respectively.

For WH sample, 8 sequences (DQ351908, DQ351909, DQ351911, DQ351914, DQ351917, DQ351929, DQ537526, DQ537529) fell into Firmicutes, 2 sequences (DQ351915, DQ351916) into $\beta$-proteobacteria, 1 sequence (DQ537528) into $\alpha$-proteobacteria, 1 sequence (DQ351912) into Actinobacteria, 1 sequence (DQ351907) into unclassified bacterium. 3 sequences (DQ351910, DQ351913, DQ537525) were grouped into $\gamma$-proteobacteria and were most closely related to Acinetobacter sp. and Halomonas sp.. For GY sample, 9 sequences (DQ351922, DQ351925, DQ351926, DQ351927, DQ351928, DQ537532, DQ537533, DQ537534, DQ537535) fell into $\beta$-proteobacteria, 3 sequences (DQ351920, DQ351921, DQ351923) into Firmicutes, 4 sequences (DQ351918, DQ351924, DQ537530, DQ537531) into $\alpha$-proteobacteria. Three sequences (DQ351920, DQ351921 and DQ537534) were closely related to Bacillus sp. SG-1 and Leptothrix discophora, the model $\mathrm{Mn}$ (II)-oxidizing bacteria from aquatic environment. Comparatively, WH sample had more Firmicutes but less $\beta$-proteobacteria clones than that of GY sample.

\section{Discussion}

In our preliminary experiments, SDS-lysis method for soil DNA isolation developed by Zhou et al. (1996) were used to extract DNA from the $\mathrm{Fe}-\mathrm{Mn}$ nodules, but DNA extracts could not be successfully amplified under the same PCR conditions. $\mathrm{Fe}(\mathrm{III})$ and $\mathrm{Mn}(\mathrm{IV})$ were present in $\mathrm{Fe}-\mathrm{Mn}$ nodules with high concentration (Tan et al., 2000). We observed some color changes during the DNA extraction process, possibly indicating intense chemical oxidation reaction during the DNA extraction. Bias in DNA recovery may be resulted from inefficient of cell lysis especially in the spore-producing Gram-positive cells, adsorption of DNA to sample particles, and chelation of DNA by metals (He et al., 2005). In the present study, a joint method combined with physical (bead-beating), chemical (SDS-lysis) and enzymatic (lysozyme and protease $\mathrm{K}$ ) was used to DNA recovery from the nodules, which was demonstrated to be effective to break the cell. Moreover, poly(A), with similar chemical characteristics of DNA, could compete the adsorption sites on the surface of sample particles with DNA so that the adsorption of DNA to particle can be reduced. The efficient cell lysis and the desorption of poly(A) make it possible to recover the trace DNA from the Fe-Mn nodules. Zhang et al. (2005) recovered DNA successfully from rock samples with the similar method. Because the $\mathrm{Fe}-\mathrm{Mn}$ nodules may contain very small amount of DNA, a further purification step would reduce the amount of DNA. Diluting template sample could abate interference of those substances in the PCR instead of further purification.

Manganese oxidization bacteria are ubiquitous in a wide range of environments and phylogenetically diverse, which mainly belonged to low-GC Gram-positive bacteria (Firmicutes), $\quad \beta$-proteobacteria and $\gamma$-proteobacteria branches of the domain bacteria based on the 16S rRNA sequences (Nealson et al., 1988; Tebo et al., 1984, 2004; Templeton et al., 2005). Phylogenetic anlyses of 16S rDNA sequences from $\mathrm{Fe}-\mathrm{Mn}$ nodule from $\mathrm{WH}$ and $\mathrm{GY}$ samples indicated that there were various bacteria inhabitating in the two soil $\mathrm{Fe}-\mathrm{Mn}$ nodules and the presence of possible $\mathrm{Mn}$ (II)-oxidizing bacteria could be originated from a diverse community. Three (DQ351913, DQ537525 and DQ351910) of the 16 clones from WH sample were affiliated with $\gamma$-proteobacteria. DQ351913 and DQ537525 shared the high similarity (95\% and 99\%) with A. lwoffii, and DQ351910 was 98\% similar with Halomonas sp.. Isolates marine $\mathrm{Fe}-\mathrm{Mn}$ nodules originally in the two genera have been demonstrated bearing high $\mathrm{Mn}(\mathrm{II})$ oxidizing activity (Templeton et al., 2005). Possible evidence for $\mathrm{Mn}(\mathrm{II})$-oxidizing bacteria existing in the nodules also comes from clones (DQ351920, DQ351921, DQ537534 and DQ537531) of the GY sample. DQ351920 and DQ351921 showed $94 \%$ and $92 \%$ similarity with Bacillus sp. SG-1, respectively, and DQ537534 was 92\% similar to $L$. discophor. The two bacteria, as the model $\mathrm{Mn}(\mathrm{II})$-oxidizing bacteria belong to Firmicutes and $\beta$-proteobacteria lineages, have been well studied (Tebo et al., 2004). The clone DQ537531 in $\alpha$-proteobacteria lingeage was $92 \%$ similar to an uncultured bacteria clone from Green Bay ferromanganous micronodule (Stein et al., 2001). The high sequence similarity reveals the presence of some organisms related to the known $\mathrm{Mn}$ (II)-oxidizing bacteria from aquatic environment and they may play significant role in the formation of soil $\mathrm{Fe}-\mathrm{Mn}$ nodules. The species, their physiological function of $\mathrm{Mn}(\mathrm{II})$ oxidation, and possible mechanism involving in the biological catalyzing of $\mathrm{Mn}$ (II) oxidization, need further 
investigation. Moreover, the comparative study of the microbial communities of $\mathrm{Fe}-\mathrm{Mn}$ nodules and the surrounding soil samples may shed light on the evolution of microbial communities, because a $\mathrm{Fe}-\mathrm{Mn}$ nodule is a relatively separated niche and may represent the soil microbial communities at its forming stages.

\section{Acknowledgments}

The funding support to JZH from the Natural Science Foundation of China (40571082, 50621804) and the Ministry of Science and Technology of China (2005CB121105) is acknowledged.

\section{References}

Burns, R.G., Burns, V.M., 1975. Mechanisms for nucleation and growth of manganese nodules. Nature 255, 130-131.

Cowen, J.P., Massoth, G.j., Baker, E.T., 1986. Bacterial scavenging of Mn and $\mathrm{Fe}$ in a mid- to far-field hydrothermal particle plume. Nature 322, 169-171.

Cowen, J.P., Massoth, G.J., Feely, R.A., 1990. Scavenging rates of dissolved manganese in a hydrothermal vent plume. Deep Sea Research 37, 1619-1637.

Douka, C., 1977. Study of bacteria from manganese concretions. Soil Biology and Biochemistry 9, 89-97.

Fuller, C.C., Harvey, J.W., 2000. Reactive uptake of trace metals in the hyporheic zone of a mining-contaminated stream, Pinal Creek, Arizona. Environmental Science and Technology 34, 1150-1155.

Hall, T.A. (Ed.), 1999. BioEdit: a user-friendly biological sequence alignment editor and analysis program for Windows 95/98/NT, Nucleic Acids Symposium Series 41, 95-98.

Harvey, J.W., Fuller, C.C., 1998. Effect of enhanced manganese oxidation in the hyporheic zone on basin-scale geochemical mass balance. Water Resources Research 34, 623-636.

He, J.Z., Xu, Z.H., Hughes, J., 2005. Pre-lysis washing improves DNA extraction from a forest soil. Soil Biology and Biochemistry 37, 2337-2341.

Kay, J.T., Conklin, M.H., Fuller, C.C., O'Day, P.A., 2001. Processes of nickel and cobalt uptake by a manganese oxide forming sediment in Pinal Creek, globe mining district, Arizona. Environmental Science and Technology 35, 4719-4725.

Kim, H.S., Pasten, P.A., Gaillard, J.F., Stair, P.C., 2003. Nanocrystalline todorokite-like manganese oxide produced by bacterial catalysis. Journal of the American Chemical Society 125, 14284-14285.

Kumar, S., Tamura, K., Nei, M., 2004. MEGA3: integrated software for molecular evolutionary genetics analysis and sequence alignment. Briefings in Bioinformatics 5, 150-163.

Lane, D.J., 1991. 16S/23S rRNA sequencing. In: Stackebrandt, E., Goodfellow, M. (Eds.), Nucleic Acid Techniques in Bacterial Systematics. Wiley, Chichester, England, pp. 115-175.

Liu, F., Colombo, C., Adamo, P., He, J.Z., Violante, A., 2002. Trace elements in manganese-iron nodules from a Chinese alfisol. Soil Science Society of America Journal 66, 661-670.
McKenzie, R.M., 1989. Manganese oxides and hydroxides. In: Dixon, J.B., Weed, S.B. (Eds.), Minerals in Soil Environments, second ed. Soil Science Society of America Book Series No. 1., pp. 439-465.

Nealson, K.H., Tebo, B.M., Rosson, R.A., 1988. Occurrence and mechanisms of microbial oxidation of manganese. Advances in Applied Microbiology 33, 279-318.

Stein, L.Y., Duc, LaM.T., Grundl, T.J., Nealson, K.H., 2001. Bacterial and archaeal populations associated with freshwater ferromanganous micronodules and sediments. Environmental Microbiology 3, 10-18.

Sullivan, L.A., Koppi, A.J., 1992. Manganese oxide accumulations associated with some soil structural pores. I. Morphology, composition and genesis. Australian Journal of Soil Research 30, 409-427.

Tan, W.F., Liu, F., Li, Y.H., He, J.Z., Li, X.Y., 2000. Mineralogy of manganese in iron-manganese nodules of several soils in China. Acta Pedologica Sinica 37, 192-201.

Tebo, B.M., 1991. Manganese(II) oxidation in the suboxic zone of the Black Sea. Deep Sea Research 38 (Suppl), S883-S905.

Tebo, B.M., Emerson, S., 1985. The effect of oxygen tension, Mn(II) concentration and temperature on the microbially catalyzed $\mathrm{Mn}$ (II) oxidation rate in a marine fjord. Applied and Environmental Microbiology 50, 1268-1273.

Tebo, B.M., Emerson, S., 1986. Microbial manganese (II) oxidation in the marine environment: a quantitative study. Biogeochemistry 2, 149-161.

Tebo, B.M., Nealson, K.H., Emerson, S., Jacobs, L., 1984. Microbial mediation of $\mathrm{Mn}(\mathrm{II})$ and $\mathrm{Co}(\mathrm{II})$ precipitation at the $\mathrm{O}_{2} / \mathrm{H}_{2} \mathrm{~S}$ interfaces in two anoxic fjords. Limnology and Oceanography 29, 1247-1258.

Tebo, B.M., Ghiorse, W.C., Waasbergen, vanL.G., Siering, P.L., Caspi, R., 1997. Bacterially-mediated mineral formation: insights into manganese(II) oxidation from molecular genetic and biochemical studies. In: Banfield, J.F., Nealson, K.H. (Eds.), Geomicrobiology: Interactions between Microbes and Minerals. Mineralogical Society of America, Washington, DC, pp. 225-266.

Tebo, B.M., Bargar, J.R., Clement, B.G., Dick, G.J., Murray, K.J., Parker, D., Verity, R., Webb, S.M., 2004. Biogenic manganese oxides: properties and mechanisms of formation. Annual Review of Earth and Planetary Sciences 32, 287-328.

Templeton, A.S., Staudigel, H., Tebo, B.M., 2005. Diverse Mn(II)oxidizing bacteria isolated from submarine basalts at Loihi Seamount. Geomicrobiology Journal 22, 127-139.

Van Cappellen, P., Viollier, E., Roychoudhury, A., Clark, L., Ingall, E., Lowe, K., Dichristina, T., 1998. Biogeochemical cycles of manganese and iron at the oxic-anoxic transition of a stratified marine basin (Orca Basin, Gulf of Mexico). Environmental Science and Technology 32, 2931-2939.

Wehrli, B., Friedl, G., Manceau, A., 1995. Reaction rates and products of manganese oxidation at the sediment-water interface. Aquatic Chemistry 244, 111-134.

White, G.N., Dixon, J.B., 1996. Iron and manganese distribution in nodules from a young Texas vertisol. Soil Science Society of America Journal 60, 1254-1262.

Zhang, G.X., Dong, H.L., Xu, Z.Q., Zhao, D.G., Zhang, C.L., 2005. Microbial diversity in ultra-high-pressure rocks and fluids from the Chinese continental scientific drilling project in China. Applied and Environmental Microbiology 71, 3213-3227.

Zhou, J.Z., Bruns, M.A., Tiedje, J.M., 1996. DNA recovery from soils of diverse composition. Applied and Environmental Microbiology 62, 316-322. 